\title{
PENGARUH PERSEPSI ATAS REWARD DAN PENILAIAN KINERJA TERHADAP KEPUASAN KERJA DAN KOMITMEN PEGAWAI NEGERI SIPIL (PNS) DI PEMERINTAH KABUPATEN LUMAJANG
}

Oleh:

AVISENA HARKAT *)

Tujuan dari penelitian ini adalah untuk menguji pengaruh reward intrinsik terhadap kepuasan kerja pegawai di Pemerintah Kabupaten Lumajang, menguji pengaruh reward ekstrinsik terhadap kepuasan kerja pegawai di Pemerintah Kabupaten Lumajang, menguji pengaruh penilaian kinerja terhadap kepuasan kerja pegawai di Pemerintah Kabupaten Lumajang, menguji pengaruh reward intrinsik terhadap komitmen pegawai di Pemerintah Kabupaten Lumajang, menguji pengaruh reward ekstrinsik terhadap komitmen pegawai di Pemerintah Kabupaten Lumajang, menguji pengaruh penilaian kinerja terhadap komitmen pegawai di Pemerintah Kabupaten Lumajang, dan menguji pengaruh kepuasan kerja pegawai terhadap komitmen pegawai di Pemerintah Kabupaten Lumajang. Teknik pengumpulan data dalam penelitian ini adalah kuesioner, wawancara dan observasi. Populasi dalam penelitian ini adalah semua pegawai Pemerintah Kabupaten Lumajang yang mempunyai golongan kepangkatan mulai golongan 1 (satu) sampai golongan 4 (empat) tahun 2012 yang berjumlah 6.487 orang.

\section{Kata Kunci : Reward, Penilaian Kinerja, Kepuasan, Komitmen}

\section{PENDAHULUAN}

\subsection{Latar Belakang Masalah}

Kualitas pegawai negeri sebagai pelayan masyarakat sangat penting dalam menunjang kelancaran penyelenggaraan pemerintah dan pelaksanaan pembangunan. Kedudukan dan peranan Pegawai Negeri Sipil adalah penting dan menentukan, karena Pegawai Negeri Sipil adalah unsur aparatur Negara yang berperan menyelenggarakan pemerintahan dan pembangunan dalam rangka usaha mencapai tujuan nasional.

Seringkali perilaku PNS terkait dengan sistem penghargaan (reward system) yang berlaku untuk PNS yang tergolong masih belum memadai. Pendapatan yang diterima PNS dari sistem penghargaan yang ada secara umum dianggap belum mencukupi sehingga pegawai mencari alternatif penghasilan dengan bekerja di tempat lain untuk menutupi kebutuhan yang tidak terpenuhi. Akibatnya aparat tidak dapat berkonsentrasi dalam menjalankan tugas utamanya sebagai Pegawai Negeri Sipil.

\section{Rumusan Masalah}

Berdasarkan uraian latar belakang masalah, diambil rumusan masalah sebagai berikut:

a. Apakah reward intrinsik berpengaruh signifikan terhadap kepuasan kerja pegawai di
Pemerintah Kabupaten Lumajang ?

b. Apakah reward ekstrinsik berpengaruh signifikan terhadap kepuasan kerja pegawai di Pemerintah Kabupaten Lumajang ?

c. Apakah penilaian kinerja berpengaruh signifikan terhadap kepuasan kerja pegawai di Pemerintah Kabupaten Lumajang ?

d. Apakah reward intrinsik berpengaruh signifikan terhadap komitmen pegawai di Pemerintah Kabupaten Lumajang ?

e. Apakah reward ekstrinsik berpengaruh signifikan terhadap komitmen pegawai di Pemerintah Kabupaten Lumajang ?

f. Apakah penilaian kinerja berpengaruh signifikan terhadap komitmen pegawai di Pemerintah Kabupaten Lumajang ?

g. Apakah kepuasan kerja pegawai berpengaruh signifikan terhadap komitmen pegawai di Pemerintah Kabupaten Lumajang ?

2. Tujuan dan Manfaat Penelitian Adapun tujuan penelitian ini adalah:

a. Untuk menguji pengaruh reward intrinsik terhadap kepuasan kerja pegawai di Pemerintah Kabupaten Lumajang;

b. Untuk menguji pengaruh reward ekstrinsik terhadap kepuasan kerja pegawai di Pemerintah Kabupaten Lumajang;

c. Untuk menguji pengaruh penilaian kinerja terhadap kepuasan kerja pegawai di 
Pemerintah Kabupaten Lumajang

d. Untuk menguji pengaruh reward intrinsik terhadap komitmen pegawai di Pemerintah Kabupaten Lumajang;

e. Untuk menguji pengaruh reward ekstrinsik terhadap komitmen pegawai di Pemerintah Kabupaten Lumajang;

f. Untuk menguji pengaruh penilaian kinerja terhadap komitmen pegawai di Pemerintah Kabupaten Lumajang;

g. Untuk menguji pengaruh kepuasan kerja pegawai terhadap komitmen pegawai di Pemerintah Kabupaten Lumajang.

\section{Manfaat Penelitian}

Hasil penelitian ini diharapkan akan dapat memberikan beberapa manfaat antara lain:

a. Bagi Pemerintah

1) Sebagai input bagi pihak pegawai di Pemerintah Kabupaten Lumajang dalam menetapkan kebijakan-kebijakan yang berkaitan dengan upaya memperbaiki, mempertahankan atau meningkatkan kepuasan kerja, sehingga dapat meningkatkan komitmen pegawai.

2) Sebagai dasar dalam menetapkan pola penilaian pegawai secara lebih teratur dan berkesinambungan dalam rangka memelihara komitmen yang tinggi terhadap instansi kerja.

b. Bagi Akademisi

1) Landasan ilmu pengetahuan, khususnya yang berkaitan dengan masalah pengaruh persepsi reward intrinsik dan reward ekstrinsik, serta penilaian kinerja terhadap kepuasan kerja dan komitmen pegawai di Pemerintah Kabupaten Lumajang.

2) Bahan referensi bagi pihak-pihak yang berkeinginan melakukan penelitian lebih lanjut tentang masalah kepuasan kerja dan komitmen pegawai.

\section{METODE PENELITIAN}

\section{Rancangan Penelitian}

Rancangan penelitian merupakan suatu rencana kegiatan yang dibuat oleh peneliti untuk memecahkan masalah, sehingga akan diperoleh data yang sesuai dengan tujuan penelitian.

Jenis penelitian yang dilakukan dalam penelitian ini diklasifikasikan sebagai explanatory research, yaitu penelitian yang menjelaskan hubungan kausal dan menguji keterkaitan antara beberapa variabel melalui pengujian hipotesis atau penelitian penjelasan (Tjiptono, 2004). Penelitian ini dilakukan pada pegawai Pemerintah Kabupaten Lumajang.

\subsection{Populasi dan Sampel}

3.2.1 Populasi

Populasi atau universe menurut Singarimbun dan Effendi (1995:152), ialah jumlah keseluruhan dari unit analisa yang ciri-cirinya akan diduga. Populasi dalam penelitian ini adalah semua pegawai Pemerintah Kabupaten Lumajang yang berjumlah 6.487 orang.

\subsubsection{Sampel Penelitian}

Sampel adalah bagian dari populasi yang diharapkan dapat mewakili populasi secara keseluruhan. Hal ini sejalan dengan pendapat Tampubolon (1970:2) yang mengatakan bahwa sampel adalah Universe Partial (sebagian yang diseleksi) sedemikian rupa sehingga dapat digeneralisasi keseluruhan universe dengan hanya menyelidiki beberapa dari satuan-satuan.

\section{Pengumpulan Data}

\section{Jenis dan Sumber Data}

Jenis dan sumber data yang dibutuhkan dalam penelitian ini adalah data primer, dilakukan dengan cara menyebar daftar pertanyaan kepada responden yang terpilih sebagai sampel penelitian untuk memperoleh data berupa tanggapan responden mengenai variabel penelitian.

\section{Teknik Pengumpulan Data}

Metode pengumpulan data yang digunakan dalam penelitian ini adalah :

a. Kuesioner : memperoleh data dengan memberikan pertanyaan tertulis (angket) yang digunakan untuk memperoleh informasi dari responden

b. Wawancara : memperoleh data dengan memberikan pertanyaan langsung pada responden.

c. Dokumentasi : memperoleh data sekunder bersumber dari unit pengelola kegiatan.

\section{Identifikasi Variabel}

Variabel-variabel dalam penelitian ini antara lain :

a. Variabel eksogen adalah variabel penyebab, yaitu variabel yang tidak dipengaruhi variabel sebelumnya. Pada studi ini terdapat dua variabel eksogen dan dinotasikan dengan $\mathrm{X}$. Ketiga variabel eksogen meliputi:
1) Reward Intrinsik $\left(\mathrm{X}_{1}\right)$
2) Reward Ekstrinsik $\left(\mathrm{X}_{2}\right)$
3) Penilaian Kinerja $\left(X_{3}\right)$ 
b. Variabel endogen adalah variabel akibat, yaitu variabel yang dipengaruhi variabel eksogen baik langsung atau tidak langsung. Pada studi ini variabel endogen dinotasikan dengan $\mathrm{Y}_{2}$, yaitu : Komitmen.

c. Variabel Intervening adalah variabel yang memiliki pengaruh kontingen yang kuat pada hubungan variabel independen - variabel dependen. Pada studi ini variabel intervening dinotasikan dengan $\mathrm{Y}_{1}$, yaitu Kepuasan.

\section{Definisi Operasional Variabel}

Berdasarkan identifikasi variabel, maka berikut akan dijelaskan definisi operasional variabel yang akan diteliti.

a. Reward intrinsik $\left(\mathrm{X}_{1}\right)$ indikatornya terdiri dari keotonomian tugas, signifikansi pekerjaan dengan prestasi, imbalan ketrampilan dan pengalaman kerja, imbalan pada diri berupa kecintaan pada pekerjaan

b. Reward ekstrinsik $\left(\mathrm{X}_{2}\right)$ Indikatornya terdiri dari kondisi kerja, kesempatan karier, kenaikan pangkat dan jabatan, pemberian penghargaan sesuai dengan prestasi

c. Penilaian Kinerja $\left(\mathrm{X}_{3}\right)$ Indikatornya terdiri dari kemampuan mengukur kinerja, deskripsi pekerjaan, penilai, standar kinerja, objektivitas proses penilaian

d. Kepuasan $\left(\mathrm{Y}_{1}\right)$ Indikatornya terdiri dari kondisi kerja, informasi, hubungan kerja, kerjasama.

e. Komitmen $\left(\mathrm{Y}_{2}\right)$; Komitmen terhadap organisasi dapat dibedakan menjadi komitmen terhadap perusahaan (company commitment) dan komitmen terhadap perserikatan (union commitment).

\section{Skala Pengukuran}

Dalam penelitian ini instrumen yang digunakan adalah daftar pertanyaan (kuesioner) yang berisi sejumlah pernyataan tertutup tentang operasional variabel-variabel penelitian.Skala yang digunakan dalam penelitian ini adalah Skala Likert. Skala Likert merupakan skala yang mengukur kesetujuan atau ketidaksetujuan seseorang terhadap serangkaian pernyataan berkaitan dengan keyakinan atau perilaku mengenai suatu objek tertentu (Hermawan, 2005: 132). Skala ini umumnya menggunakan lima angka penilaian, yaitu:
a. Sangat setuju $=$ skor 5
b. Setuju $=$ skor 4
c. Cukup Setuju = skor 3
d. Tidak setuju $=$ skor 2
e. Sangat tidak setuju $=$ skor 1

\section{Uji Validitas}

Dalam suatu penelitian, data mempunyai kedudukan yang sangat penting. Hal ini dikarenakan data merupakan penggambaran variabel yang diteliti dan berfungsi sebagai alat pembuktian hipotesis.

Uji validitas dilakukan dengan menggunakan analisis faktor konfirmatori (confirmatory faktor analysis) pada masing masing variabel laten. Indikator - indikator dari suatu variabel dikatakan valid jika mempunyai loading faktor signifikan pada $(\lambda=5 \%)$. Instrumen penelitian tersebut valid unidimensional jika mempunyai nilai goodness of fit index (GFI) > 0,90 .

\section{Uji Reliabilitas}

Selain harus valid, instrumen juga harus reliabel (dapat diandalkan). Instrumen dikatakan reliabel apabila alat ukur tersebut memperoleh hasil-hasil yang konsisten. Reliabilitas konstruk dinilai dengan menghitung indeks reliabilitas instrumen yang digunakan dalam model SEM (Structural Equation Modelling).

\section{Uji Asumsi Structural Equation Modeling ( SEM )}

Setelah diajukan uji validitas dan reliabilitas pada masing-masing variabel laten, maka dilakukan uji asumsi untuk melihat apakah prasyarat yang diperlukan dalam permodelan SEM (Structural Equation Modelling) dapat terpenuhi. Prasyarat yang harus dipenuhi adalah asumsi multivariat normal, tidak adanya multikolinearitas atau singularitas dan outlier.

\section{Uji Normalitas}

Normalitas yaitu sebaran data yang akan dianalisis, untuk melihat apakah asumsi normalitas dapat dipenuhi sehingga data dapat diolah lebih lanjut untuk permodelan SEM ini.

\section{Uji Multikolinearitas}

Multikolinearitas dapat dilihat melalui determinan matriks kovarians. Nilai determinan yang sangat kecil atau mendekati nol, menunjukkan indikasi terdapatnya masalah multikolinearitas atau singularitas, sehingga data itu tidak dapat digunakan datam penelitian (Tabahruck and Fideti (1998) dalam Ghozali 2008:231).

\section{Uji Outliers}

Outliers adalah kondisi observasi dari suatu data yang memiliki karakteristik unik yang terlihat sangat berbeda jauh dari observasi-observasi lainnya yang muncul dan dalam bentuk nilai 
ekstrim, baik untuk sebuah variabel tunggal ataupun variabel kombinasi (Hair et al, 1998 dalam Ghozali 2008:227).

\section{Structural Equation Modeling (SEM)}

Analisis data dilakukan dengan melalui kegiatan mengelompokkan data sejenis dalam suatu tabel (tabulasi), dan menganalisis data dengan melakukan perhitungan-perhitungan menurut metode penelitian kuantitatif dengan teknik analaisis yang akan digunakan adalah Structural Equation Modelling (SEM) dengan menggunakan program software AMOS (Analysis of Moment Structure) 16.0. sebagai salah satu teknik analisis multivariate.

Adapun karakteristik utama dari Structural Equation Modelling (SEM) pada berikut ini :

1. Estimasi hubungan ketergantungan ganda (multivariate dependence relationship);

2. Memungkinkan untuk mewakili konsep yang sebelumnya tidak teramati dalam hubungan yang ada serta memperhitungkan kesalahan pengukuran dalam proses estimasi.

Structural Equation Modelling (SEM) memungkinkan untuk melakukan estimasi atas sejumlah persamaan regresi yang berbeda, tetapi terkait satu sama lain secara bersamaan, dengan membuat model struktural.

\section{HASIL DAN PEMBAHASAN \\ Hasil Penelitian \\ Deskriptif Karakteristik Responden}

Karakteristik responden digunakan oleh peneliti untuk memberikan informasi mengenai data demografi responden (umur, jenis kelamin, pendidikan, dan lama bekerja), sedangkan deskriptif variabel penelitian berguna untuk mendukung hasil analisis data yang menyajikan distribusi hasil jawaban responden atas pertanyaan-pertanyaan penelitian.

\section{Diskripsi Variabel}

Analisis deskriptif ditujukan untuk mengamati kecenderungan-kecenderungan dan penyimpangan data setiap variabel penelitian (tendency central) melalui mean indikator indikatornya masing - masing. Baiknya persepsi terhadap variabel reward intrinsik dapat dilihat melalui pegawai merasa pekerjaan yang dilakukan oleh semua pegawai memiliki keotonomian tugas pekerjaan sendiri-sendiri, pegawai merasa pekerjaan yang dilakukan memiliki signifikansi dengan prestasi kerja yang dicapai oleh masingmasing pegawai, pegawai merasa pekerjaan yang dilakukan memberikan imbalan pada dirinya berupa ketrampilan dan pengalaman kerja, dan pegawai cukup merasa pekerjaan yang dilakukan memberikan imbalan pada dirinya berupa kecintaan pada pekerjaan setiap pegawai.

Reward ekstrinsik $\left(\mathrm{X}_{2}\right)$ di Pemerintah Kabupaten Lumajang dipersepsikan "sangat baik" oleh sebagian besar pegawai. Sangat baiknya persepsi terhadap variabel reward ekstrinsik dapat dilihat melalui pegawai merasa kondisi fisik (kebersihan dan tata ruang kerja, penerangan, dan sirkulasi udara) di tempat kerja cukup memadai, pegawai merasa instansi sering memberikan kesempatan setiap pegawai untuk mengembangkan kariernya, pegawai merasa instansi selalu memperhatikan kenaikan pangkat dan jabatan setiap pegawai, dan pegawai merasa instansi selalu memberikan penghargaan bagi pegawai yang memiliki prestasi kerja.

Penilaian kinerja $\left(\mathrm{X}_{3}\right)$ di Pemerintah Kabupaten Lumajang dipersepsikan "baik" oleh sebagian besar pasien pegawai. Baiknya persepsi terhadap variabel penilaian kinerja dapat dilihat melalui metode penilaian DP3 yang selama ini digunakan Pemerintah Kabupaten Lumajang benar-benar dapat mengukur kinerja pegawai dengan baik.

Kepuasan kerja $\left(\mathrm{Y}_{1}\right)$ di Pemerintah Kabupaten Lumajang dipersepsikan "cukup baik" oleh sebagian pegawai. Cukup baiknya persepsi terhadap variabel kepuasan kerja dapat dilihat melalui Pemerintah Kabupaten Lumajang cukup menciptakan kondisi kerja terbaik yang dapat diberikan pada pegawai untuk melakukan pekerjaan, pegawai memperoleh segala informasi yang diperlukan untuk menyelesaikan tugas dengan cukup baik, hubungan antar teman sekerja harus berlangsung cukup baik dan lancar, dan teman-teman sekerja cukup dapat bekerjasama saling mendukung dan saling membantu.

Komitmen pegawai $\left(\mathrm{Y}_{2}\right)$ di Pemerintah Kabupaten Lumajang dipersepsikan "cukup baik" oleh sebagian besar pegawai. Cukup baiknya persepsi terhadap variabel komitmen pegawai dapat dilihat melalui pegawai cukup mematuhi segala peraturan yang ditetapkan oleh instansi, memahami dan menjalankan nilai-nilai yang berlaku di perusahaan serta mengintegrasikan kepentingan individu sejalan dengan tujuan perusahaan.

\section{Uji Validitas}

Suatu tes atau alat instrumen dapat dikatakan mempunyai validitas tinggi apabila alat tersebut menjalankan fungsi ukurnya atau memberikan hasil ukur yang sesuai dengan tujuan pengukuran tersebut. 


\section{Uji Reliabilitas}

Reliabilitas adalah ukuran konsistensi internal dari indikator-indikator sebuah variabel bentukan yang menunjukkan derajat sampai dimana masing-masing indikator itu mengindikasikan sebuah variabel bentukan yang umum.

\section{Uji Asumsi Structural Equation Modelling (SEM)}

Setelah dilakukan uji validitas dan reliabilitas pada masing - masing variabel laten, maka dilakukan uji asumsi untuk melihat apakah prasyarat yang diperlukan dalam permodelan SEM dapat terpenuhi. Prasyarat yang harus dipenuhi adalah asumsi multivariat normal, tidak adanya multikolinearitas atau singularitas dan outlier.

\section{Uji Normalitas}

Uji normalitas perlu dilakukan baik untuk normalitas terhadap data univariat maupun normalitas multivariat dimana beberapa variabel yang digunakan sekaligus dalam analisis akhir. Untuk menguji ada atau tidaknya asumsi normalitas, maka dapat dilakukan dengan dengan nilai statistik $\mathrm{z}$ untuk skewness dan kurtosisnya secara empirik dapat dilihat pada Critical Ratio (CR) yang digunakan tingkat signifikansi 5\%, maka nilai CR yang berada diantara $-1,96$ sampai dengan 1,96 $(-1,96 \leq \mathrm{CR} \leq 1,96)$ dikatakan data berdistribusi normal, baik secara univariat maupun secara multivariat (Ghozali, 2005:128).

\section{Uji Multikolinearitas}

Multikolinearitas dapat dilihat melalui determinan matriks kovarians. Nilai determinan yang sangat kecil atau mendekati nol, menunjukkan indikasi terdapatnya masalah multikolinearitas atau singularitas, sehingga data tersebut tidak dapat digunakan untuk penelitian (Tabachnick and Fidell, 1998, dalam Ghozali, 2005:131).

\section{Uji Outliers}

Outliers adalah observasi yang muncul dengan nilai ekstrim baik secara univariat maupun secara multivariat yaitu muncul karena kombinasi karakteristik unik yang dimiliki dan terlihat sangat jauh berbeda dari observasi-observasi lainnya.

Hasil uji outliers dalam penelitian ini menunjukkan besarnya nilai Mahalanobis $d$ squared. Data dengan probabilitas ( $\mathrm{p}$ ) yaitu $\mathrm{p} 1$ dan p2 lebih besar dari 38,932 berarti mengalami outliers dan sebaliknya p1 dan p2 lebih besar lebih kecil dari 38,932 berarti tidak mengalami outliers. Berdasarkan hasil pengujian diperoleh nilai p1 dan p2 lebih kecil dari 38,932 berarti tidak mengalami outliers atau dapat dikatakan tidak ada perbedaan yang signifikan antara data dengan kelompok data.

\section{Uji Kausalitas}

Setelah dilakukan pengujian kesesuian modal penelitian, maka langkah selanjutnya adalah menguji kausalitas dalam penelitian. Hasil pengujian koefisien jalur untuk pengaruh reward intrinsik $\left(\mathrm{X}_{1}\right)$ terhadap kepuasan kerja $\left(\mathrm{Y}_{1}\right)$ memiliki jalur positif sebesar 0,358 dengan C.R sebesar 1,198 dan probabilitas (p) sebesar 0,046 yang berarti bahwa reward intrinsik berpengaruh signifikan terhadap kepuasan kerja. Sehingga hipotesis yang menyatakan bahwa reward intrinsik berpengaruh signifikan terhadap kepuasan kerja di Pemerintah Kabupaten Lumajang terbukti kebenarannya atau $\mathrm{H}_{1}$ diterima.

Hasil pengujian koefisien jalur untuk pengaruh reward ekstrinsik $\left(\mathrm{X}_{2}\right)$ terhadap kepuasan kerja $\left(\mathrm{Y}_{1}\right)$ memiliki jalur positif sebesar 0,177 dengan C.R sebesar 2,235 dan probabilitas (p) sebesar 0,023 yang berarti bahwa reward ekstrinsik berpengaruh signifikan terhadap kepuasan kerja. Sehingga hipotesis yang menyatakan bahwa reward ekstrinsik berpengaruh signifikan terhadap kepuasan kerja di Pemerintah Kabupaten Lumajang terbukti kebenarannya atau $\mathrm{H}_{2}$ diterima.

Hasil pengujian koefisien jalur untuk pengaruh penilaian kinerja $\left(\mathrm{X}_{3}\right)$ terhadap kepuasan kerja $\left(\mathrm{Y}_{1}\right)$ memiliki jalur positif sebesar 0,250 dengan C.R sebesar 2,266 dan probabilitas (p) sebesar 0,023 yang berarti bahwa penilaian kinerja berpengaruh signifikan terhadap kepuasan kerja. Sehingga hipotesis yang menyatakan bahwa penilaian kinerja berpengaruh signifikan terhadap kepuasan kerja di Pemerintah Kabupaten Lumajang terbukti kebenarannya atau $\mathrm{H}_{3}$ diterima

Hasil pengujian koefisien jalur untuk pengaruh reward intrinsik $\left(\mathrm{X}_{1}\right)$ terhadap komitmen pegawai $\left(\mathrm{Y}_{2}\right)$ memiliki jalur positif sebesar 0,358 dengan C.R sebesar 2,112 dan probabilitas (p) sebesar 0,035 yang berarti bahwa reward intrinsik berpengaruh signifikan terhadap komitmen pegawai. Sehingga hipotesis yang menyatakan bahwa reward intrinsik berpengaruh signifikan terhadap komitmen pegawai di Pemerintah Kabupaten Lumajang terbukti kebenarannya atau $\mathrm{H}_{4}$ diterima.

Hasil pengujian koefisien jalur untuk pengaruh reward ekstrinsik $\left(\mathrm{X}_{2}\right)$ terhadap komitmen pegawai $\left(\mathrm{Y}_{2}\right)$ memiliki jalur positif sebesar 0,054 dengan C.R sebesar 0,772 dan probabilitas (p) sebesar 0,440 yang berarti bahwa 
reward ekstrinsik tidak berpengaruh signifikan terhadap komitmen pegawai. Sehingga hipotesis yang menyatakan bahwa reward ekstrinsik berpengaruh signifikan terhadap komitmen pegawai di Pemerintah Kabupaten Lumajang tidak terbukti kebenarannya atau $\mathrm{H}_{5}$ ditolak.

Hasil pengujian koefisien jalur untuk pengaruh penilaian kinerja $\left(\mathrm{X}_{3}\right)$ terhadap komitmen pegawai $\left(\mathrm{Y}_{2}\right)$ memiliki jalur positif sebesar 0,260 dengan C.R sebesar 2,432 dan probabilitas (p) sebesar 0,015 yang berarti bahwa penilaian kinerja berpengaruh signifikan terhadap komitmen pegawai. Sehingga hipotesis yang menyatakan bahwa penilaian kinerja berpengaruh signifikan terhadap komitmen pegawai di Pemerintah Kabupaten Lumajang terbukti kebenarannya atau $\mathrm{H}_{6}$ diterima..

Hasil pengujian koefisien jalur untuk pengaruh kepuasan kerja $\left(\mathrm{Y}_{1}\right)$ terhadap komitmen pegawai $\left(\mathrm{Y}_{2}\right)$ memiliki jalur positif sebesar 0,260 dengan C.R sebesar 2,432 dan probabilitas (p) sebesar 0,029 yang berarti bahwa kepuasan kerja berpengaruh signifikan terhadap komitmen pegawai. Sehingga hipotesis yang menyatakan bahwa kepuasan kerja berpengaruh signifikan terhadap komitmen pegawai di Pemerintah Kabupaten Lumajang terbukti kebenarannya atau $\mathrm{H}_{7}$ diterima.

\section{Pengaruh Antar Variabel}

a. Pengaruh Langsung Antar Variabel Dalam penelitian hubungan pengaruh langsung terjadi antara variabel laten eksogen yang terdiri dari reward intrinsik $\left(\mathrm{X}_{1}\right)$, reward ekstrinsik $\left(\mathrm{X}_{2}\right)$, dan penilaian kinerja $\left(\mathrm{X}_{3}\right)$ dengan variabel endogen intervening kepuasan kerja $\left(\mathrm{Y}_{1}\right)$ dan variabel laten endogen terikat yaitu komitmen pegawai $\left(\mathrm{Y}_{2}\right)$.

Besarnya pengaruh langsung variabel reward intrinsik terhadap kepuasan kerja adalah sebesar 0,287, besarnya pengaruh langsung variabel reward ekstrinsik terhadap kepuasan kerja adalah sebesar 0,277 , besarnya pengaruh langsung variabel penilaian kinerja terhadap kepuasan kerja adalah sebesar 0,290, besarnya pengaruh langsung variabel reward intrinsik terhadap komitmen pegawai adalah sebesar 0,284 , besarnya pengaruh langsung variabel reward ekstrinsik terhadap komitmen pegawai adalah sebesar 0,084, besarnya pengaruh langsung variabel penilaian kinerja terhadap komitmen pegawai adalah sebesar 0,299, dan besarnya pengaruh langsung variabel kepuasan kerja terhadap komitmen pegawai adalah sebesar 0,310 .

Pengaruh Tidak Langsung Antar Variabel
Hubungan tidak langsung terjadi antara variabel laten eksogen yang terdiri dari reward intrinsik $\left(\mathrm{X}_{1}\right)$, reward ekstrinsik $\left(\mathrm{X}_{2}\right)$, dan penilaian kinerja $\left(\mathrm{X}_{3}\right)$ dengan variabel endogen intervening kepuasan kerja $\left(\mathrm{Y}_{1}\right)$ dan variabel laten endogen terikat yaitu komitmen pegawai $\left(\mathrm{Y}_{2}\right)$.

\section{Pengaruh Tidak Langsung Antar Variabel}

Pengaruh tidak langsung variabel reward intrinsik, reward ekstrinsik, dan penilaian kinerja bernilai positif terhadap komitmen pegawai. Besarnya pengaruh tidak langsung variabel reward intrinsik terhadap komitmen pegawai adalah sebesar 0,089, besarnya pengaruh tidak langsung variabel reward ekstrinsik terhadap komitmen pegawai adalah sebesar 0,86 , besarnya pengaruh tidak langsung variabel penilaian kinerja terhadap komitmen pegawai adalah sebesar 0,090.

\section{Pengaruh Total Antar Variabel}

Pengaruh total merupakan pengaruh yang disebabkan oleh adanya berbagai hubungan antar variabel baik langsung maupun tidak langsung. Besarnya pengaruh total variabel reward intrinsik terhadap kepuasan kerja adalah sebesar 0,287, besarnya pengaruh total variabel reward ekstrinsik terhadap kepuasan kerja adalah sebesar 0,277, besarnya pengaruh total variabel penilaian kinerja terhadap kepuasan kerja adalah sebesar 0,290, besarnya pengaruh total variabel reward intrinsik terhadap komitmen pegawai adalah sebesar 0,373, besarnya pengaruh total variabel reward ekstrinsik terhadap komitmen pegawai adalah sebesar 0,170 , besarnya pengaruh total variabel penilaian kinerja terhadap komitmen pegawai adalah sebesar 0,389, dan besarnya pengaruh total variabel kepuasan kerja terhadap komitmen pegawai adalah sebesar 0,310 .

\section{PEMBAHASAN}

Secara garis besar penelitian ini menunjukkan secara umum hipotesis yang diajukan dapat diterima. Dalam hal ini terdapat pengaruh yang signifikan reward intrinsik terhadap kepuasan kerja dan komitmen pegawai, terdapat pengaruh yang signifikan reward ekstrinsik terhadap kepuasan kerja, terdapat pengaruh yang signifikan penilaian kinerja terhadap kepuasan kerja dan komitmen pegawai, dan terdapat pengaruh yang signifikan kepuasan kerja terhadap komitmen pegawai.

\section{Pengaruh Reward Intrinsik terhadap Kepuasan Kerja Pegawai}

Hasil penelitian menunjukkan faktor reward intrinsik mempunyai pengaruh yang 
signifikan terhadap kepuasan kerja. Hal ini berarti semakin baik reward intrinsik, maka kepuasan kerja juga akan semakin baik. Berkaitan dengan reward intrinsik, pada kantor Pemerintah Kabupaten Lumajang aspek-aspek reward intrinsik telah tercipta dengan baik.

\section{Pengaruh Reward Ekstrinsik terhadap Kepuasan Kerja Pegawai}

Hasil penelitian menunjukkan faktor reward ekstrinsik mempunyai pengaruh yang signifikan terhadap kepuasan kerja. Hal ini berarti semakin baik reward ekstrinsik, maka kepuasan kerja juga akan semakin baik. Berkaitan dengan reward ekstrinsik, pada kantor Pemerintah Kabupaten Lumajang aspek-aspek reward ekstrinsik telah tercipta dengan baik.

\section{Pengaruh Penilaian Kinerja terhadap Kepuasan Kerja Pegawai}

Hasil penelitian menunjukkan faktor penilaian kinerja mempunyai pengaruh yang signifikan terhadap kepuasan kerja. Hal ini berarti semakin baik penilaian kinerja, maka kepuasan kerja juga akan semakin baik. Berkaitan dengan penilaian kinerja, pada kantor Pemerintah Kabupaten Lumajang aspek-aspek penilaian kinerja telah tercipta dengan baik. Penilaian kinerja dapat digunakan untuk memverifikasi bahwa karyawan telah memenuhi standar kerja yang telah ditetapkan.

\section{Pengaruh Reward Intrinsik terhadap Komitmen Pegawai}

Hasil penelitian menunjukkan faktor reward intrinsik mempunyai pengaruh yang signifikan terhadap komitmen pegawai. Hal ini berarti semakin baik reward intrinsik, maka komitmen pegawai juga akan semakin baik.

Hal ini dapat dipahami karena sistem penghargaan (reward instrinsik) sebagai bentuk rangsangan yang diberikan sesuai dengan apa yang dipersepsikan aparat. Dengan demikian pegawai menganggap bahwa pekerjaan merupakan bagian yang sangat penting. Oleh karena itu pegawai memandang organisasi merupakan obyek yang harus ditempatkan sebagai bagian penting dalam hidupnya, sehingga tercipta komitmen organisasi dari para Pegawai Negeri Sipil.

\section{Pengaruh Reward Ekstrinsik terhadap Komitmen Pegawai}

Hasil penelitian menunjukkan faktor reward ekstrinsik mempunyai pengaruh yang tidak signifikan terhadap komitmen pegawai. Hal ini berarti peningkatan reward ekstrinsik tidak diikuti oleh peningkatan komitmen pegawai secara langsung, dapat disimpulkan bahwa komitmen organisasi adalah sikap yang dimiliki individu dengan nilai-nilai dan tujuan yang hendak dicapai organisasi, sehingga individu tersebut ingin selalu mempertahankan keanggotaannya dalam organisasi, dan ingin selalu memberikan kontribusi yang terbaik bagi organisasi.

\section{Pengaruh Penilaian Kinerja terhadap Komitmen Pegawai \\ Hasil penelitian menunjukkan faktor} penilaian kinerja mempunyai pengaruh yang signifikan terhadap komitmen pegawai. Hal ini berarti semakin baik penilaian kinerja, maka komitmen pegawai juga akan semakin baik.

Hasil penilaian kinerja dapat dijadikan sebagai bahan evauasi untuk melaksanakan proses manajemen selanjutnya seperti untuk mutasi, promosi, kenaikan pangkat, pengembangan pegawai, dan sebagainya. Penilaian kinerja dapat digunakan untuk memverifikasi bahwa karyawan telah memenuhi standar kerja yang telah ditetapkan.

\section{Pengaruh Kepuasan Kerja Pegawai terhadap Komitmen Pegawai}

Hasil penelitian menunjukkan faktor kepuasan kerja mempunyai pengaruh yang signifikan terhadap kepuasan kerja berpengaruh signifikan terhadap komitmen pegawai di Pemerintah Kabupaten Lumajang terbukti kebenarannya atau $\mathrm{H}_{7}$ diterima. Hal ini berarti semakin baik kepuasan kerja, maka komitmen pegawai juga akan semakin baik. Berkaitan dengan kepuasan kerja, pada kantor Pemerintah Kabupaten Lumajang aspek-aspek kepuasan kerja telah tercipta dengan baik.

\section{Pengaruh Langsung, Tidak Langsung dan Pengaruh Total \\ Pengaruh variabel reward intrinsik,} reward ekstrinsik, dan penilaian kinerja terhadap kepuasan kerja maupun komitmen pegawai serta variabel kepuasan kerja terhadap komitmen pegawai dapat dilihat baik secara langsung, tidak langsung, maupun secara total. Besarnya pengaruh total variabel reward intrinsik terhadap kepuasan kerja adalah sebesar 0,287 yang juga merupakan pengaruh langsung, besarnya pengaruh total variabel reward ekstrinsik terhadap kepuasan kerja adalah sebesar 0,277 yang juga merupakan pengaruh langsung, besarnya pengaruh total variabel penilaian kinerja terhadap kepuasan kerja 
adalah sebesar 0,290 yang juga merupakan pengaruh langsung.

Pengaruh langsung variabel reward intrinsik terhadap komitmen pegawai adalah sebesar 0,284 sedangkan pengaruh tidak langsung variabel reward intrinsik terhadap komitmen pegawai adalah sebesar 0,089. Mengacu pada hasil tersebut, pengaruh langsung variabel reward intrinsik terhadap komitmen pegawai lebih besar dibandingkan dengan pengaruh tidak langsungnya.

Besarnya pengaruh langsung reward ekstrinsik terhadap komitmen pegawai adalah sebesar 0,084 sedangkan pengaruh tidak langsung reward ekstrinsik terhadap komitmen pegawai sebesar 0,086.

Besarnya pengaruh langsung variabel penilaian kinerja terhadap komitmen pegawai adalah sebesar 0,299 dan pengaruh tidak langsung variabel penilaian kinerja terhadap komitmen pegawai sebesar 0,090 .

Besarnya pengaruh total variabel kepuasan kerja terhadap komitmen pegawai adalah sebesar 0,310 yang juga merupakan pengaruh langsung.

\section{KESIMPULAN DAN SARAN}

\section{Kesimpulan}

Berdasarkan analisis yang telah dilakukan pada penelitian ini, maka dapat ditarik kesimpulan sebagai berikut:

1. Reward intrinsik berpengaruh signifikan terhadap kepuasan kerja pegawai di Pemerintah Kabupaten Lumajang.

2. Reward ekstrinsik berpengaruh signifikan terhadap kepuasan kerja pegawai di Pemerintah Kabupaten Lumajang.

3. Penilaian kinerja berpengaruh signifikan terhadap kepuasan kerja pegawai di Pemerintah Kabupaten Lumajang.

4. Reward intrinsik berpengaruh signifikan terhadap komitmen pegawai di Pemerintah Kabupaten Lumajang.

5. Reward ekstrinsik tidak berpengaruh signifikan terhadap komitmen pegawai di Pemerintah Kabupaten Lumajang.

6. Penilaian kinerja berpengaruh signifikan terhadap komitmen pegawai di Pemerintah Kabupaten Lumajang.

7. Kepuasan kerja pegawai berpengaruh signifikan terhadap komitmen pegawai di Pemerintah Kabupaten Lumajang.

\section{Saran}

Mengacu pada kesimpulan di atas, maka dapat dapatdiberikan saran sebagai berikut.

a. Bagi pihak Kantor Pemerintah Kabupaten Lumajang, hasil penelitian ini menunjukkan bahwa variabel motivasi kerja, disiplin kerja, dan lingkungan kerja mampu meningkatkan kepuasan kerja dan kinerja pegawai. Oleh karena itu, hendaknya pihak Pemerintah Kabupaten Lumajang selalu memperhatikan komponen-komponen yang berkaitan dengan faktor-faktor tersebut, seperti pemenuhan kebutuhan pegawai melalui kebijakan gaji yang sesuai dengan kondisi perekonomian, pemberian penghargaan kepada pegawai sesuai dengan pencapaian prestasi, serta penciptaan lingkungan kerja yang baik dan kondusif.

b. Berkaitan dengan penilaian kinerja yang memiliki pengaruh terbesar terhadap kepuasan kerja dan komitmen pegawai, maka hendaknya Pemerintah Kabupaten Lumajang menggunakan metode penilaian DP3 yang tepat, objektif, serta melibatkan pegawai.

c. Hasil penelitian menunjukkan bahwa reward ekstrinsik dapat memengaruhi komitmen pegawai secara tidak langsung melalui kepuasan kerja, dalam hal ini pihak Pemerintah Kabupaten Lumajang harus terlebih dahulu menciptakan kepuasan atas pemberian penghargaan ekstrinsik seperti dengan menciptakan kondisi kerja yang baik, adanya kesempatan bagi setiap pegawai untuk mengembangkan kariernya, proses kenaikan pangkat dan jabatan setiap pegawai, serta pemberian penghargaan bagi pegawai yang memiliki prestasi kerja.

\section{DAFTAR PUSTAKA}

Akrioyd, D., B. Richards, and T. O'Brien. 2002. The Predictive Value Selected Intrinsic and Extrinsic Rewards As Determinants of Health Occupations Teacher' Work Satisfaction: Journal of Health Occupation Education. 7. 2. 1-22. North Carolina.

Akrioyd, D., B. Richards, and T. O'Brien. 2002. The Predicting The organizational Commitment of Marketing Education and Health Occupations Teacher by Work Related Rewards: Journal Industrial Teacher Education. 32. 1. 1-14. North CarolinaAlbanes, Robert, and Fleet, David D. Van, 1983. 
Organization Behavior: Managerial View Point, New York: The Dryden Press cd.

Algifari, 2000. Analisis Regresi: Teori, Kasus dan Solusi. Edisi ke-2. Cetakan ke1. Yogyakarta: BPFE.

Arbuckle, J.L. and Wothke W. 1999. Amos 5.1 User's Guide : SPSS Small Waters Corporation.

Arikunto, Suharsimi. 2002. Prosedur Penelitian Suatu Pendekatan Praktek. Edisi Revisi ke-5. Jakarta: Rineka Cipta.

Cohen et al. 1992. Effective Behavior in Organizations. 5th Edition. Boston, MA: Richard D. Irwin, Inc.

Davis, Duane, and Cosenza, Robert M. 1993. Business Research for Decision Making. California: Wadsworth.

Deluca, Metthew J. 1991. Compensation Management. New Jersey: Prentice Hall.

Ferdinand, Augusty, 2000, Structural Equation Modeling dalam Penelitian Manajemen, ikatan Penerbit Universitas Diponogoro, Semarang.

Gannon, Martin J. 1977. Management An Oraganizational Perspective. Boston Toronto: Press Little Brown.

Gibson et al. 2003. Organizations Behavior structure Processes. 11th Edition. New York: MacGraw Hill Irwin.

Gibson, Ivancevich, Dornely, 1992, Organisasi perilaku, Stuktur, Proses, Edisi ke - 5, cetakan ke - 5, Erlangga, Jakarta..

Pierce, Jon L., and Gardner, Donald G., with Durham, Randall . 2002. Management, Organizational Behavior, An Integrated Perspective. Ohio: South Western, Thomson Learning. 